\title{
Quaternary Vegetation History of the Lower Bengal Basin (India) Inferred from Palaeo-palynological Analysis
}

\author{
Payel Roy and Nimai Chandra Barui
}

\author{
Palaeopalynological Section, Department of Botany, Surendranath College, 24/2 \\ Mahatma Gandhi Road, Kolkata-700009, West Bengal, India
}

\begin{abstract}
Black peat samples deposited in between sandy clay layers were collected from an uncovered profile at Rajarhat, 24 Paraganas (N), $20 \mathrm{~km}$ extreme North East of the city of Kolkata, $\left(22^{\circ} 34^{\prime} \mathrm{N}, 88^{\circ} 30^{\prime} \mathrm{E}\right)$ West Bengal. The profile resulted from an excavation made during the construction of a multistory building. Palynological investigations of the peat samples revealed a large deposits of pollen grains of mangrove species such as Heritiera, Excoecaria, Rhizophora, Sonneratia, Avicennia, Bruguiera, Nypa, Barringtonia, Phoenix paludosa, Aegiceras etc. Pollen grains of grasses, some freshwater plants, as well as fern spores (such as Acrostichum, Pteris, Pteridium and Polypodium) were also recovered in large quantities. All were found from a peat layer formed at a depth of about $5.35 \mathrm{~m}$ to $6.14 \mathrm{~m}$ from the surface. The fossil pollen assemblage found indicates the prevalence of a past typical mangrove vegetation, which is presently observed in the Sundarbans region (a mangrove swamps, about $85 \mathrm{~km}$ south of greater Kolkata). The present study reflects a low lying landscape frequently transgressed by sea water and getting supply of fresh water from rivers. Ecological and edaphic factors such as increase of salinity, submergence, reclamation, flood etc. could have been responsible for any vegetation fluctuations.
\end{abstract}

Key words: biostratigraphy, mangrove, palaeo-environment, pollen analysis

\section{INTRODUCTION}

Pollen analysis has a wide-range of applications towards palaeo-ecological reconstruction of vegetation, correlation among stratigraphic sequences, and determination of the past palaeo-environment in tropical and subtropical regions etc. To this end, a study of fossil pollens to understand the Quaternary biostratigraphy, palaeoecology, vegetation history and mapping are surprisingly still insufficient in India. Available reports from different Quaternary deposits, especially from the Bengal Basin and a few other places can only transmit an approximate idea about the divergence of palaeoenvironmental conditions ranging from tropical desert to temperate climate. The vegetation of Eastern India is governed by a complex of environmental features including climate, geology, soil character, forest organization, biotic factor and history of the forest formation. The climax vegetation of lower Bengal Basin has been destroyed and the pattern of existing distribution of the biota was largely changed by various edaphic factors (Naskar, 2004).

Fossiliferous peat layers have been recorded in different locations of the Bengal Basin. Pollen analysis and dating of the relevant deposits have helped determine the past vegetation and consequently the time of deposition and have also provided the lithostratigraphical sequence and character. The predicted climate changes might have a 
large influence on its particular environment and dense population as well as on mitigation and adjustment scenarios (IPCC, 2007).

Determination of sea level changes and reconstruction of the past vegetation of Chilika lake were done from analysis of palynological deposits by Khandelwal et al. (2008). Late Quaternary deposits of mangrove swamps served as stratigraphic markers in the Kerala Konkan Basin (Kumaran et al., 2005). The distribution patterns of pollen grains at 9000 and $18,000{ }^{14} \mathrm{C} \mathrm{BP}$ (last maximum) time-slices was reported by Hooghiemstra et al. (2006) based on pollen records from eleven marine sediments between Portugal and the Gulf of Guinea where considerable latitudinal migrations of vegetation belts were taken into consideration.

The Lower Bengal Basin encompasses the immense area of the Indo-Gangetic plain, and it is the drainage basin of three important rivers, namely; Ganga, Brahmaputra, and Meghna. The largest delta in a single block is represented by innumerable tributaries and distributaries in the Indian subcontinent at the Bay of Bengal and suggests an intense formation of diversified mangrove vegetation and wide captivating species diversity.

On tropical coasts, mangrove ecosystem is specific to the environment and the vegetation is considered as a good peat producer.

The potential of tropical peat soils as palaeo-climatic indicators was illucidated by Sukumar et al. (1993). Vegetation is ruled by the complex of environmental features including climate, geomorphic characteristics of the substratum, soil character, forest organization, biotic factors and history of the forest formation. Any modifications in hydrological or tidal influences could result in severe variations in the vegetation pattern. According to Blasco et al. (1996), salinity tolerance (with respect to substrate salinity, inundation regime, duration of saline immersion) of some halophyte species like Rhizophora, Bruguiera, Sonneratia, Heritiera, and Nypa is directed by tectonic, sedimentological or hydrological parameters. These species either re-adjust to the changed climatic condition or renunciate to precarious status.

The elevated deposition of peaty soil by overflowing along the South Indian coast caused indiscretion and devastation of the mangrove vegetation during 8000-6000 BP (Narayana et al., 2002). Mangrove forests thrived only sporadically over the late Quaternary and below the present sea level, the inherited patterns of these swamps are found (Crowley, 1996). Based on the perspective of Banerjee and Sen (1987) the subsurface distribution of mangrove remnants could be a sea level indicator in a stratigraphic sequence of the past. In this context, a palaeo-palynological study could emphasize the link between coastal vegetation formation and sea level changes (Rull, 1998).

The present day distribution pattern of the Sundarbans mangrove vegetation is mainly affected by several biotic factors, including eastward tilting of the Bengal plate, rapid sedimentation (more than $0.7 \mathrm{~cm} /$ year), marked subsidence (more than $0.5 \mathrm{~cm} /$ year) toward the west, increasing anthropogenic influences (including large scale land reclamation) and decreasing fresh water influx from the river system (Bhattacharya et al., 2006). Several workers have already established this view (Sen and Banerjee, 1990; Hait et al., 1994a, 1996; Stanley and Hait, 2000). Assessment of past vegetation and comparing it with the present can be determined by a quantitative estimation and comparative study of fossil pollen deposits.

The present study attempted to provide a better understanding of the actual palaeoenvironmental conditions of the mangrove forest in the non-swampy region of the Bengal Basin over different geological eras and to determine transitional zones between the marine and the fresh water environment. It provides valuable information for the proper mapping of the Quaternary deposition in the Bengal Basin and a comprehensive conclusion regarding the diversity of halophytic vegetation and change of climate during the Quaternary Period in the Bengal Basin. The present paper deals with palaeo-palynological investigation accompanied with ${ }^{14} \mathrm{C}$ dating of undisturbed peat samples collected from Rajarhat, 24 Paraganas (N) about $20 \mathrm{~km}$ extreme north east of Kolkata. The samples were 
collected from a profile excavated during a building construction and consequently palynologically examined confirming the vegetation history during the Quaternary period. The present area is now a densely populated suburb of greater Kolkata, leading to change of vegetation forcefully by demographic compulsion. In this context, the increased human activities in the area impose the impact of climate change on the vegetation (Njokuocha 2012). The changes of vegetation pattern over time from typical mangrove vegetation to terrestrial habitat can be determined by the analysis of pollen assemblages from the single peat layer.

\section{MATERIALS AND METHODS}

Fresh peat samples were collected from an uncovered profile at Rajarhat, 24 Paraganas (N), $20 \mathrm{~km}$ North East of the city of greater Kolkata, $\left(22^{\circ} 34^{\prime} \mathrm{N}, 88^{\circ} 30^{\prime} \mathrm{E}\right)$ (Figure 1) West Bengal. The excavation was made in connection with the construction work of a multistorv buildino.
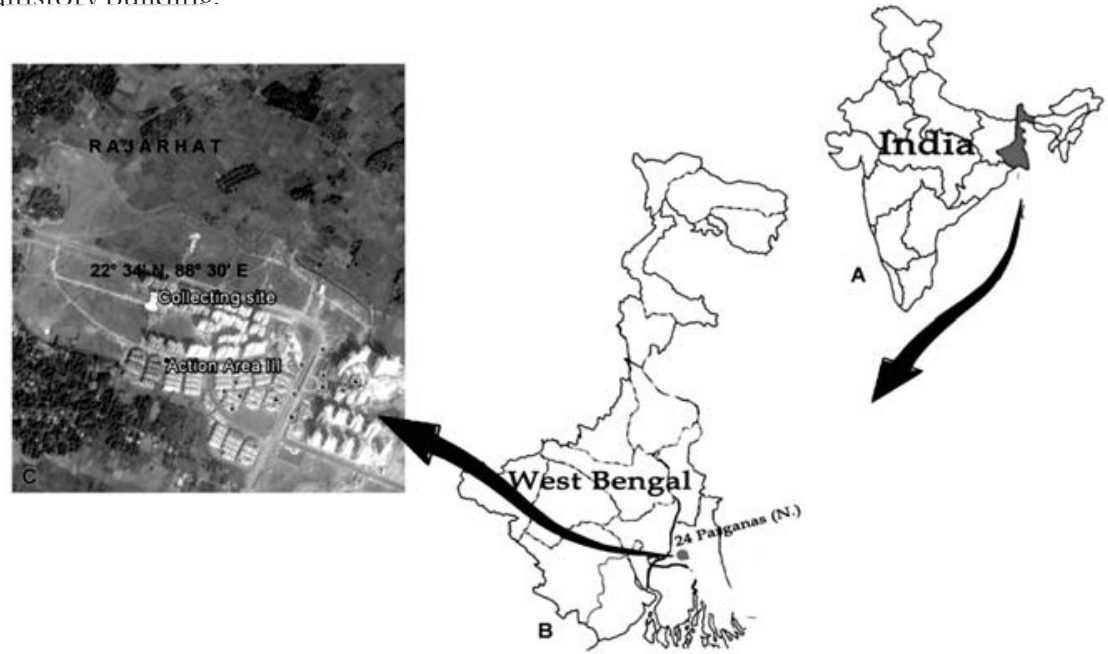

Figure 1. A-C. The exact location of the study area. A-location of the country India; B- state West Bengal; C-Rajarhat, 24 Parganas $(\mathrm{N})$, collection site(from google earth).

The whole profile from surface to bottom was about $6.44 \mathrm{~m}$. From the bottom, the single peat layer overlaid a $0.3 \mathrm{~m}$ thick sandy clay layer and it was $0.79 \mathrm{~m}$ in thickness. Above this layer was a sandy clay layer $3.85 \mathrm{~m}$ thick followed by a dry disturbed soil of $1.5 \mathrm{~m}$ (Table. 1). A total of 20 peat samples were collected from the deposits for palynological investigation and two samples were sent to the Birbal Sahni Institute of Palaeobotany, Lucknow, India for ${ }^{14} \mathrm{C}$ dating. The lithostratigraphy of the investigated profile is illustrated in Figure. 2D.

Table 1. Rajarhat profile, lithostratigraphy and ${ }^{14} \mathrm{C}$ dating.

\begin{tabular}{llc}
\hline \multicolumn{1}{c}{ Depth } & \multicolumn{1}{c}{ Sediment } & Dating \\
\hline Surface & \multicolumn{1}{c}{-} & - \\
$0.0-1.5 \mathrm{~m}$ & Yellow dry, disturbed soil & - \\
$1.5-3.5 \mathrm{~m}$ & Sandy clay, yellow & - \\
$5.35-6.14 \mathrm{~m}$ & Black Peat & $4690-5060$ BP (BSIP dated) \\
$6.14-6.44 \mathrm{~m}$ & Sandy clay, grey & - \\
\hline
\end{tabular}


Palynological analysis of the collected samples was done using the standard acetolysis method (Faegri and Iversen, 1975). The samples were boiled in 10\% KOH solution and treated with hydrofluoric acid to eliminate humic substances and sand particles. Pollen grains were counted under the microscope at high power objective (40x) and finally identified by comparing with the recent reference slides of fossil pollen grains and confirming with earlier works (Thanikaimoni, 1987; Das and Ghose, 1990). Individual pollen grains were prepared for photomicrography and viewed under $10 \mathrm{x}$ and $40 \mathrm{x}$ objectives of a fluorescence microscope (Figure 3). For the understanding of palaeoenvironmental spectra, a composite pollen diagram of the peat layer is provided. Most of the pollen grains were identified down to their generic or family level only.

\section{RESULTS AND DISCUSSION}

The black peat layer was deposited at a depth of $5.35-6.14 \mathrm{~m}$ from the surface lying between two sandy clay layers; a yellow layer above and a grey layer below. ${ }^{14} \mathrm{C}$ dating revealed that it was deposited during the period between 4690Y BP and 5060YBP. (Figure 2D).The composite pollen diagram shows that this peat layer consisted of both arboreal pollen (total AP) and non-arboreal pollen (NAP) where more important types have been represented (Figure 2A, B, and C). Pollen and spore identification was kept at generic or family level only as in most of the cases, identification down to the species level was not possible. On the basis of the vegetation assemblages and their distribution, the pollen diagram could not be divided into zones. From the twenty random peat samples taken for total pollen count, the existence of a grassland vegetation confirmed by the dominance of pollen from wild (25.07\%) and cultivated (10.35\%) grasses was found. Other grasslandassociated taxa were also present such as Ipomoea $(1.29 \%)$ and Typha $(3.9 \%)$. Aside from the grassland floristic elements, the peat layer also revealed pollen of a large number of mangrove genera such as tricolporate, sub-prolate grains of Heritiera $(2.39 \%)$; tricolporate, prolate and reticulate grains of Excoecaria (2.25\%), Barringtonia (2.59\%), Bruguiera $(0.77 \%)$ and Sonneratia (2.1\%); monosulcate, bilaterally symmetric grains of Phoenix (4.13\%); monosulcate, spheroidal, echinate grains of Nypa (2.01\%); tricolporate, prolate grains of Avicennia (2.58\%), Rhizophora (1.76\%), Aegiceras(0.89\%) and Ceriops (0.81\%). Other mangrove associates like Acanthus (3.23\%), Amaranthaceae/ Chenopodiaceae (3.93\%) and some ferns such as Acrostichum (4.27\%), Pteris (4.17\%) Pteridium(4.86)and Polypodium $(6.17 \%)$ were also found.

The pollen assemblages indicate vegetation dominated by non-arboreal over arboreal taxa. The pollen diagram indicates the presence of halophytes consisting of a large number of true mangrove species, namely; Heritiera, Excoecaria, Bruguiera, Barringtonia, Nypa, Phoenix, Sonneratia, Suaeda, Rhizophora, along with the mangrove associate Acanthus, which is usually associated with marshy habitat due to the presence of fresh water plants and ferns. These pollen assemblages were in a fairly good preserved state. During the time of their deposition, Heritiera was dominant taxon. At present, Heritiera population has decreased considerably and is almost at the verge of extinction at the western part of the Sunderbans (Barui, 2011; Das, 2014).

Previous studies (Barui and Chanda, 1992, 1995a, 1995b, 1997,1998, Barui, 2003, Barui and Sengupta, 2004, Barui 2011, Das 2014) done on the two sides of the River Hoogly of the Bengal Basin showed the existence of a halophytic vegetation dominated by mangrove plants, which, to some extent is similar to the present-day vegetation of the Sundarbans.

Pollen analysis further revealed the existence of a mosaic type of landscape in the area which consisted of a mix of swampy, marshy and terrestrial habitats during the period 5050 BP-4690 BP. It was also revealed that plants from brackish and freshwater habitats 
were present and occurred in a fluctuating manner, which could only be attributed to the presence of a nearby marine ecosystem during the said period.

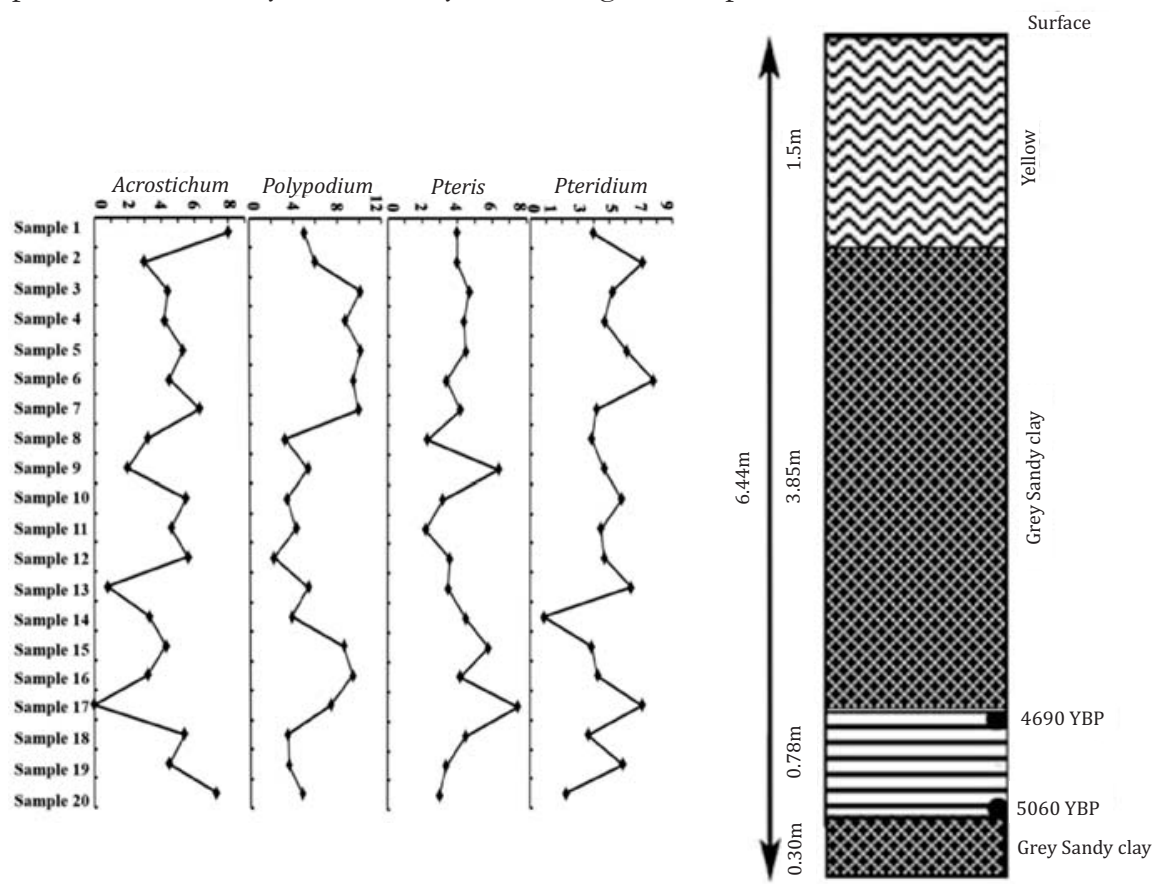

Lithostratigraphv with ${ }^{14} \mathrm{C}$ Dating

Figure 2. C - Composite pollen diagrams of the peat layer (In all the diagrams X-axis denotes pollen percentage of each sample); D- Graphical representation of the lithostratigraphy with the ${ }^{14} \mathrm{C}$ dates of the black peat layer.

The halophytic plants were represented by true mangroves like Heritiera, Excoecaria, Bruguiera, Nypa, Phoenix, Sonneratia and associated plants (like Barringtonia, Ramnaceae etc). Pollen of non-arboreal plants were also found which belong to Acanthus, Asteraceae, Ipomoea, Typha and Ludwigia. Smaller and larger pollen grains of grasses were also identified. The occurrence of a few fern spores similar to those of the fern genera Polypodium, Pteris, Pteridium and Acrostichum can be considered significant because they are not very common in present-day vegetation.

The drifting nature of Calcutta peat was reported by Vishnu-Mitre and Gupta 1972. However, in this study, a large number of pollen grains of mangrove taxa could probably indicate in situ deposition, rather than of drift origin. This is in accord with the earlier works (Barui and Chanda, 1992; Hait et al., 1996.). Barui (2011), found in peat samples from lower Bengal basin (North suburban area of Calcutta) at a depth of about $2.2 \mathrm{~m}-3.5 \mathrm{~m}$ below the surface the presence of a large number of pollens and spores of core mangroves and some freshwater plants and ferns. The age of the peat layers ranged from 2665 to 6530 BP. Mao et al (2012) published taxonomic keys for the identification of Quaternary mangrove flora of the coastal areas of south China. 


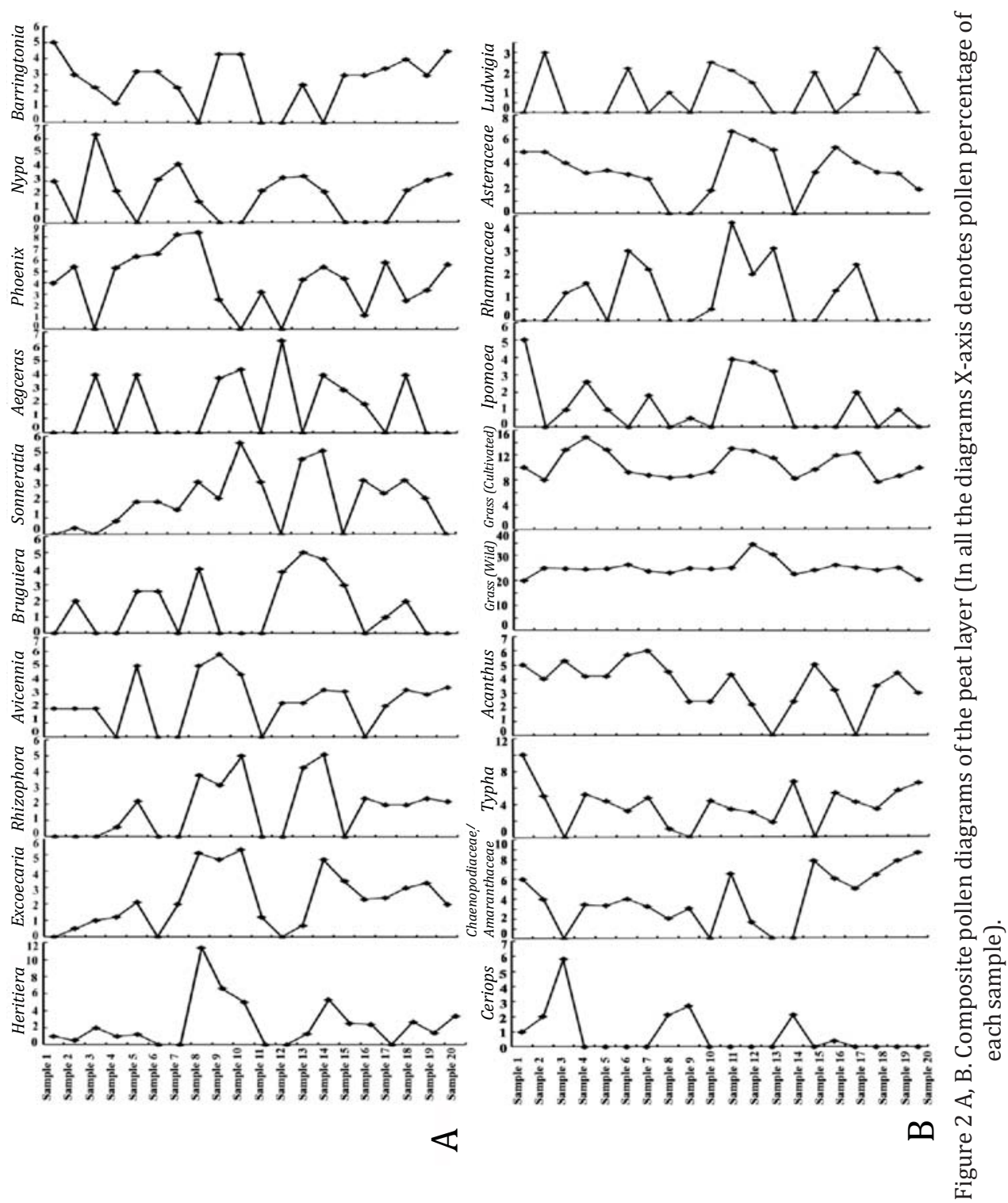




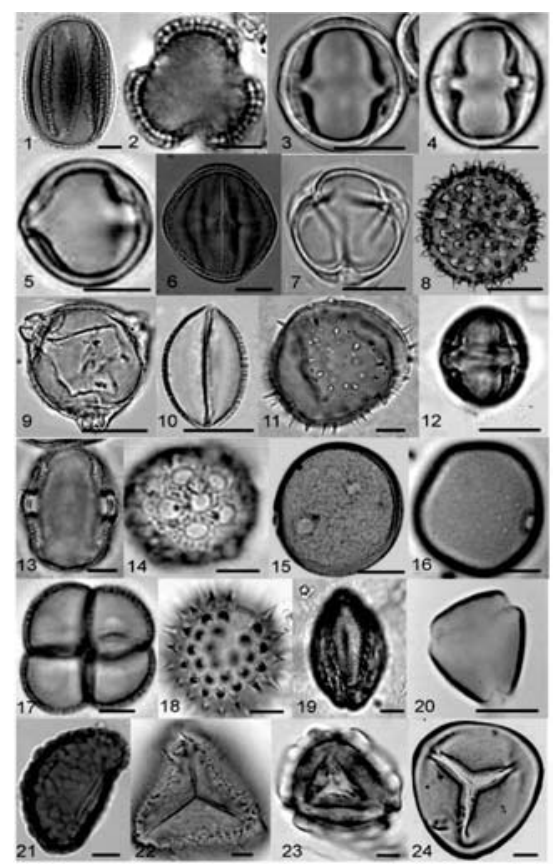

Figure 3. Photomicrographs of single pollen grains and spores recovered from the peat samples. 1. Acanthus; 2 Avicennia; 3. Aegiceras; 4. Bruguiera; 5. Ceriops; 6. Excoecaria; 7. Heritiera; 8. Ipomoea; 9. Ludwigia; 10. Phoenix; 11. Nypa; 12. Rhizophora;13. Sonneratia; 14. Amaranthaceae; 15. Poaceae (cultivated); 16. Poaceae (wild); 17. Typha; 18. Asteraceae; 19. Barringtonia; 20. Rhamnacea; 21. Polypodium;22. Acrostichum; Ptris; 24. Pteridium. (Bar represents $10 \mu \mathrm{m}$ )

Limaye and Kumaran (2012) inferred that the decline of the mangrove vegetation since $3500 \mathrm{BP}$ could be attributed to the prevailing arid climate and dwindling trends of the monsoon until $1500 \mathrm{BP}$ in the areas of south Konkan. They also noticed the emergence of mangroves in the tropical monsoon areas in the recent past. The non-arboreal pollens increased throughout the peat layer from lower (5060 YBP) to the upper stratum (4690 YBP) which indicates human influence on the vegetation of this area including the effect of agricultural land expansion.

Based on the present study and also from previous works (Barui, 2011; Das, 2014), Heritiera was the dominant forest constituent a few thousand years back as large quantities of its pollen have been recorded from all profiles analyzed. The dominant brackish nature of the substratum during 7000-2600 BP was established by the presence of Heritiera, as this plant grows up to a salinity level of $15 \mathrm{ppt}$ (Nandy et al., 2006). Heritiera is also considered as palaeo-ecological and biostratigraphic marker (Hait et al., 1994b). The fern population, that partially existed in the area, was later eliminated probably due to ecological and biotic influence or washed out to long distances by river water flow.

Studies have shown that palaeo-palynological analysis could provide information on past climatic, vegetation and landscape changes and their connection to the present vegetation. Mao et al. (2006) was able to show the most likely source plants of the present mangrove coastal swamps of Dongzhai and Qinglan, in northern Hainan Island, China based on pollen analysis. Taylor et al. (2001) concluded that the lowland vegetation history has revealed a close connection between peat formation and sea level. The palynological analysis of the core peat samples provided a higher or better resolution of time intervals in the past compared to the poor temporal resolution obtained from lacustrine sediments (Andreev et al., 2012). Their observation also suggested a basis for recreating the Holocene history of mangrove ecosystem dynamics in lower Bengal basin. 


\section{CONCLUSION}

From the present study it can be concluded that the vegetation of present day Sundarban is somewhat similar to the past $\left({ }^{14} \mathrm{C} 5060 \mathrm{BP}\right)$ halophytic swampy vegetation of Kolkata and adjoining areas. However the migration of the present mangrove forest towards the south is induced by continued river silting, occasional tectonic movements, and biotic factors (human settlement).

\section{ACKNOWLEDGMENT}

The authors would like to thank University Grant Commission (UGC) for funding this research work. We express our gratitude to the Principal of Surendranath College, Kolkata, West Bengal, India for providing proper infrastructure to conduct the study.

\section{REFERENCES}

ANDrEEV, A.A., E. MOROZOVA, G. FEDOROV, L. SCHIRRMEISTER, A. A. BOBROV, F. KIENAST and G. SCHWAMBORN, 2012. Vegetation history of Central Chukotka deduced frompermafrost paleoenvironmental records of the El'gygytgyn impact crater. Climate of the Past Discussion, 8, 1409-1441.

BANERJEE, M., and P.K. SEN. 1987. Palaeobiology in understanding the change of sea level and coastline in Bengal Basin during Holocene period. Indian Journal of Earth Science, 14: 307-320.

BANERJEE, M., and P.K. SEN. 1990. Palyno-plankton stratigraphy and environmental changes during the Holocene in theWest Bengal, India. Review of Palaeobotany and Palynology, 65: 25-35.

BARUI, N.C. 2003. Pollen analytical investigation of Holocene deposits in Bengal basin, India. In: Anupama, K., Achuythan, H., eds., South Asian PAGES Workshop and training programme. Pondicherry, 2003, 125-129.

BARUI, N.C., and S. CHANDA. 1997. Change of Holocene climate in coastal zone of West-Bengal. In: Das S N, Thakur R S (Eds.). Proceedings of International Geosphere Biosphere Programme and Regional Research Institute. Allied Publishers, Bhubaneswar, 168-172.

BARUI, N.C., and S. CHANDA. 1992. Late Quaternary pollen analysis in Relation to dating, vegetational history and Biostratigraphy of Calcutta peat. Proceedings of Indian National Science Academy, 58: 191-200.

BARUI, N.C., and S. CHANDA. 1995a. Pollen analysis of two Holocene deposits in south Bengal on western of river Hooghly. In: Proceedings of Birbal Sahni Centenary Volume, D.D. Pant Allahabad, 59-62.

BARUI, N.C., and S. CHANDA. 1995b. Holocene vegetational history of Calcutta peat (Bhawnipur). Journal of National Botanical Society, 49: 161-166.

BARUI, N.C., and S. CHANDA. 1998. Role of mangroves in understanding Palaeoclimate during Holocene in and around Calcutta. In: Guha Bakshi D N, Sanyal P, Naskar K R (Eds.). Proceedings of William Roxburgh Memorial Seminar on Sundarban Mangals. Calcutta Wildlife Society, Calcutta, 213-217.

BARUI, N.C. 2011. Floral diversity of mangrove plants with reference to palaeoenvironment during Holocene in Bengal Basin, India. Quaternary International, 229: 89-93.

BARUI, N.C., and P. SENGUPTA. 2004. Pollen analytical investigation of some peat deposits in Bengal basin. Journal of the Botanical Society of Bengal, 58: 59-62.

BLASCO, F., P. SAENGER and F. JANODET. 1996. Mangrove as indicator of coastal change.Catena,27:167-178. 
CROWLEY, G.M. 1996. Late Quaternary mangrove distribution in northern Australia. Australian Systematic Botany. 9: 219-225.

DAS, S. 2014. Palaeo-palynology of late Quaternary peat deposit from Lower Bengal Basin, India: A palaoecological approach. Quaternary International,231: 1-8.

DAS, S., and M. GHOSE. 1990. Pollen morphology of some mangrove plants of Sundarbans, West Bengal. Journal of National Botanical Society, 44: 59-75.

FAEGRI, K. and J. IVERSEN. 1975. Text Book of Pollen Analysis, third ed. (Copenhagen).

HAIT, A.K., H.K. DAS, S. CHAKRABARTY, A.K. ROY, and S. CHANDA. 1994b. On the changes in coastal Digha based on floral and faunal record. Indian Journal of Earth Science, 21: 192-198.

HAIT, A.K., H.K. DAS, S. CHAKRABARTY, A.K. ROY, and S. CHANDA. 1996. Evidence of palaeoenvironmental variation during late Quaternary of Kolaghat, Midnapore district, West Bengal. Current Science, 70: 1089-1093.

HAIT, A.K., H.K. DAS, S. CHAKRABARTY, A.K. ROY, and S. CHANDA. 1994a. On the occurrence of mangrove biota and some faunal remains from the sediments of Haldia, West Bengal in relation to its past environment. Journal of Palynology, 30: 73-78.

HOOGHIEMSTRA, H., A. LÉZINE, S.A.G. LEROY, L. DUPONT, and F. MARRET. 2006. Late Quaternary palynology in marine sediments: a synthesis of the understanding of pollen distribution patterns in the NW African setting. Quaternary International, 148: 29-44.

IPCC, 2007. Climate Change 2007: Synthesis Report, Contribution of Working Groups I, II and III to the Fourth Assessment Report of the Intergovernmental Panel on Climate Change (Core Writing Team, Edited by: Pachauri, R.K., Reisinger, A.), IPCC, Geneva, Switzerland.

KHANDELWAL, A., M. MOHANTI, F. GARCÍA-RODRÍGUEZ, and B.W. SCHARF. 2008. Vegetation history and sea level variations during the last 13,500 years inferred from pollen records at Chilika lake, Orissa, India. Vegetation History and Archaeobotany, 17:335-344.

KUMARAN, K.P.N., K.M. NAIR, M. SHINDIKAR, R.B. LIMAYE, and D. PADMALAL. 2005. Stratigraphical and palynological appraisal of the Late Quaternary mangrove deposits of the west coast of India. Quaternary Research, 64: 418-431.

LIMAYE, R.B. and K.P.N. KUMARAN, 2012. Mangrove vegetation responses to Holoceneclimate change along Konkan coast of south-western India. Quaternary International, 263:114-128

MAO, L., D.J. BATTENA, T. FUJIKIC, Z. ZHEN LID, L. DAIE, and C. WENGE. 2012. Key to mangrove pollen and spores of southern China: an aid to palynological interpretation of Quaternary deposits in the South China Sea. Review of Palaeobotany and Palynology, 176: 41-67.

MAO, L., Y. ZHANG, Y., and H. BI. 2006. Modern pollen deposits in coastal mangrove swamps from northern Hainan Island, China. Journal of Coastal Research, 22: 14231436.

NANDY (DATTA), P., M. GHOSE, R. SPOONER-HART, and S. DAS, 2006. Is Heritiera fomes lessadapted to the present conditions of the Indian Sundarban compared to othermangrove species? Annals of Tropical Research.28 (2):76-91.

NASKAR, K.R., 2004. Manual of Indian Mangroves. Daya, New Delhi, 220 pp.

NARAYANA, A.C., C.P. PRIJU, and G. RAJAGOPALAN. 2002. Late Quaternary peat deposits from Vembanad Lake (lagoon), Kerala, SW coast of India. Current Science, 83 : 318-321.

NJOKUOCHA, R.C. 2012. Holocene pollen deposits and recent vegetation distribution of Obayi Lake, Nsukka. Quaternary International, 262: 20-24. 
RULL, V. 1998. Middle Eocene mangroves and vegetational changes in the Maracaibo Basin, Venezuela. Palaeos, 13: 287-296.

STANLEY, J.D., and A.K. HAIT. 2000. Deltas, radiocarbon dating and measurements of sediment storage and subsidence. Geology, 8: 295-298.

SUKUMAR, R., R. RAMESH, R.K. PANT, and G. RAJAGOPALAN. 1993. A d13C record of late Quaternary climate change from tropical peats of southern India. Nature, 364: 703-706.

TAYLOR, D.,O.H. YEN, P.G. SANDERSON and J.Dodson, 2001. Late Quaternary peat formation and vegetation dynamics in a low land tropical swamp, Nee Soon, Singapore. Palaeogeography, Palaeoclimatology, Palaeoecology171, 269-287.

THANIKAIMONI, G. 1987. Mangrove Palynology. UNDP/UNSCO Regional Project on Training and Research on Mangrove Ecosystem. Institute Francais Pondicherry, India,. p.100.

VISHNU-MITRE and H.P. GUPTA. 1972. Pollen analytical study of Quaternary deposits in the Bengal Basin. Palaeobotanist, 18: 297-306. 